\title{
Results of heart transplantation: 18 years experience in University Hospital Dubrava, Zagreb
}

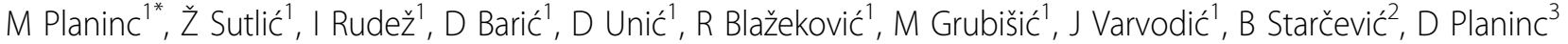 \\ From 23rd World Congress of the World Society of Cardio-Thoracic Surgeons \\ Split, Croatia. 12-15 September 2013
}

\section{Background}

Despite advances in medical treatment, development of new surgical procedures and the availability of mechanical circulatory support heart transplantation (HTx) remains the treatment of choice for end-stage heart failure. Objective of this study is to report single center experience and outcomes of patients undergoing HTx.

\section{Methods}

We retrospectively examined the outcomes from ninetyfive HTx recipients between September 1995 and May 2013. The mean recipient age was $55 \pm 8$ years, and $85 \%$ were male. Dilated cardiomyopathy was present in $40 \%$, ischemic in $30 \%$ and $30 \%$ were other causes. Ten patients $(10 \%)$ that were heart recipients from our cohort were on high urgent list of Eurotransplant. As an induction of immunosuppressive therapy we were using antithymocyte globulin, and for maintenance a combination of cyclosporine, prednisone and mycophenolate. Survival was studied using Kaplan-Meier curves.

\section{Results}

In-hospital mortality was $12 \%$. The median follow-up was 20 months. The global survival rates at 1,5 , and 10 years were $82 \%, 77 \%$, and $62 \%$ respectively. The mean survival is 105 months (95\% CI, 93.4-118.3). Early main causes of death were sepsis (41\%) and primary graft failure $(29 \%)$ and late causes were late rejection (20\%), malignant disease and other causes (10\%).

\section{Conclusion}

In our center, post-HTx survival rates at 1,5 , and 10 years were even better than those reported by the International

\footnotetext{
* Correspondence: mislav.planinc@gmail.com

'Department of Cardiac and Transplant Surgery, University Hospital Dubrava, Zagreb, Croatia
}

Full list of author information is available at the end of the article
Society of Heart and Lung Transplantation as a result of combined effort of all medical personnel involved in perioperative and postoperative management.

\section{Authors' details}

'Department of Cardiac and Transplant Surgery, University Hospital Dubrava, Zagreb, Croatia. ${ }^{2}$ Department of Cardiovascular Diseases, University Hospital Dubrava, Zagreb, Croatia. ${ }^{3}$ Department of Cardiology, University Clinical Center Sisters of Mercy, Zagreb, Croatia.

Published: 11 September 2013

\section{doi:10.1186/1749-8090-8-S1-0151}

Cite this article as: Planinc et al: Results of heart transplantation: 18 years experience in University Hospital Dubrava, Zagreb. Journal of Cardiothoracic Surgery 2013 8(Suppl 1):0151.
Submit your next manuscript to BioMed Central and take full advantage of:

- Convenient online submission

- Thorough peer review

- No space constraints or color figure charges

- Immediate publication on acceptance

- Inclusion in PubMed, CAS, Scopus and Google Scholar

- Research which is freely available for redistribution

Submit your manuscript at www.biomedcentral.com/submit
() Biomed Central

\section{() Biomed Central}

(C) 2013 Planinc et al; licensee BioMed Central Ltd. This is an Open Access article distributed under the terms of the Creative Commons Attribution License (http://creativecommons.org/licenses/by/2.0), which permits unrestricted use, distribution, and reproduction in any medium, provided the original work is properly cited. 